\title{
Wound defects in the elderly: our experience
}

\author{
A Ferrarese*, $\vee$ Martino, M Nano \\ From XXIII Annual Meeting of the Italian Society of Geriatric Surgery \\ Lecce, Italy. 2-4 December 2010
}

\section{Background}

We report our experience on clinical outcomes of elderly patients who have undergone laparoscopic repair for incisional and primary inguinal hernias.

\section{Patients and methods}

To assess the safety and efficacy of laparoscopic [1-5] primary inguinal and incisional repair we reviewed the records of our patients of over 70 years old, who underwent such a procedure from June 2007 to September 2010: hernia defect size, recurrence, operative time, and procedure-related complications [6] were evaluated and a laparoscopic approach was attempted in all patients who required a mesh repair.

We scheduled 42 patients $(32 \mathrm{M}-10 \mathrm{~F}$, with 53 wound defects totally) for laparoscopic incisional [7] and primary inguinal hernia repair and we performed 17 surgical repair for incisional hernia and 36 for primary hernia. Of those, 13 were done for incisional hernias with a single defect (24.5\% recurrence hernias), 4 with multiple defects ( $7.54 \%$ recurrence hernias), 12 were performed for unilateral inguinal hernias $(22.56 \%$ recurrence hernias), 16 for bilateral inguinal hernias (30.08\% recurrence hernias), 4 for umbilical hernias (1 recurrence hernias), 2 for epigastric and linea alba's hernias, and 2 for rectum diastasis.

The majority of the patients were normal weight with a mean BMI of $25 \mathrm{~kg} / \mathrm{m} 2$ (45\%), 38\% $25>\mathrm{BMI}>30$ (overweight), 17\% BMI > 30 (obesity).

There was no conversion to an open procedure. The mean operative time was 128 minutes (range: $50-325$ ).

In all the patients only mesh was used (37.5\% polypropylene not reabsorbable, $42.5 \%$ tridimensional polyestercollagen composite mesh, 20\% lightweight multifilament mesh partly reabsorbable) [8]. The meshes were fixed in

\footnotetext{
* Correspondence: alessia.ferrarese@gmail.com

* Correspondence: alessia.ferrarese@gmail.com
Department of Clinical and Biologic Science, School of Medicine and Surgery "S. Luigi Gonzaga" - AOU San Luigi Gonzaga - Orbassano, Turin - SCDU General Surgery University of Turin, Italy
}

C 2011 Ferrarese et al; licensee BioMed Central Ltd. This is an open access article distributed under the terms of the Creative Commons

$82.5 \%$ with absorbable fixation device, in $5 \%$ with a non-absorbable device and in $12.5 \%$ with fibrin glue [9].

In contrast to other authors [10-13], major complications were $14.24 \%$ (6/42: 2 chronic inguinal pain, 4 recurrences). Minor complications were 5/42 (11.90\%) and included only asymptomatic seromas that were aspirated. The mean hospital stay was 4.7 days (range: 1-18 days).

\section{Conclusions}

Laparoscopic repair of primary inguinal and incisional ventral hernias with transabdominal placement of composite mesh in the elderly achieves excellent results with low morbidity in comparison with open surgical approaches $^{(2,4,5)}$. In our experience, adequate fixation of the mesh, extension to cover the entire previous incision and standardization of the placement interval of the sutures are crucial to the success of the repair.

Published: 24 August 2011

\section{References}

1. Bezsilla J: Laparoscopic repair of abdominal wall hernia. Magy Seb 2010, 1(63(5)):327-332

2. Misra MC, Bansal VK, Kulkarni MP, Pawar DK: Comparison of laparoscopic and open repair of incisional and primary ventral hernia: results of a prospective randomized study. Surg Endosc 2006, 20(12):1839-45.

3. Martorana G, Carlucci M, Alia C, Barrianco G, lacopinelli SM, Labruzzo C, Noto N, Restivo FP, Viola M, Mastrandrea G: Laparoscopic incisional hernia repair: our experience and review of the literature. Chir Ital 2007, 59(5):671-7.

4. Lagares-Garcia JA, Bansidhar B, Moore RA: Benefits of laparoscopy in middle-aged patients. Surg Endosc 2003, 17(1):68-72.

5. Lomanto D, lyer SG, Shabbir A, Cheah WK: Laparoscopic versus open ventral hernia mesh repair: a prospective study. Surg Endosc 2006, 20(7):1030-5.

6. Mathonnet $M$, Mehinto $D$ : Indications for inguinal hernia repair. J Chirb (Paris) 2007, 144(4):5S11-4.

7. Tonouchi H, Ohmori Y, Kobayashi M, Kusunoki M: Trocar site hernia. Arch Surg 2004, 139(11):1248-56

8. Dabić D, Cerović S, Azanjaç B, Marić B, Kostić I: Prolene hernia system, ultrapro hernia system and $3 D$ patch devices in the treatment of inguinal, femoral, umbilical and small incisional hernias in outpatient surgery. Acta Chir lugos/ 2010, 57(2):49-54. 
9. Stefano O, Giovanni C, Luca S, Claudio P, Giuseppe V, Enrico C: Laparoscopic incisional hernia repair with fibrin glue in select patients. JSLS 2010, 14(2):240-5.

10. Rogers FB, Guzman EA: Inguinal hernia repair in a community setting: implications for the elderly. Hernia 2010, 9.

11. Genç V, Ensari C, Ergul Z, Kulacoglu H: A very late-onset deep infection after prosthetic inguinal hernia repair. Chirurgia (Bucur) 2010, 105(4):555-7.

12. Huang M, Musa F, Castillo C, Holcomb K: Postoperative bowel herniation in a 5-mm nonbladed trocar site. JSLS 2010, 14(2):289-91.

13. Malik AM, Khan A, Talpur KA, Laghari AA: Factors influencing morbidity and mortality in elderly population undergoing inguinal hernia surgery. J Pak Med Assoc 2010, 60(1):4.

doi:10.1186/1471-2318-11-S1-A15

Cite this article as: Ferrarese et al:: Wound defects in the elderly: our experience. BMC Geriatrics 2011 11(Suppl 1):A15.

\section{Submit your next manuscript to BioMed Central} and take full advantage of:

- Convenient online submission

- Thorough peer review

- No space constraints or color figure charges

- Immediate publication on acceptance

- Inclusion in PubMed, CAS, Scopus and Google Scholar

- Research which is freely available for redistribution

Submit your manuscript at www.biomedcentral.com/submit 